\title{
Pandemic Influenza Vaccines
}

\author{
Lauren J. DiMenna and Hildegund C.J. Ertl
}

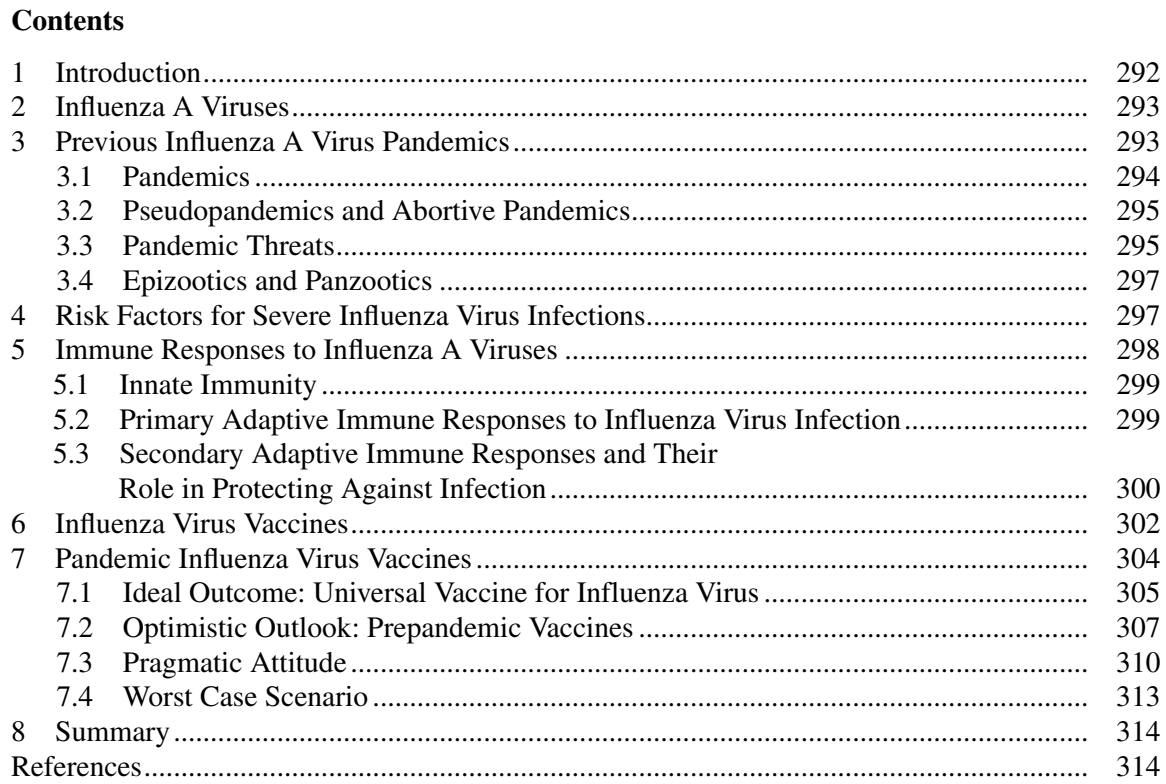

\begin{abstract}
Since their compositions remain uncertain, universal pandemic vaccines are yet to be created. They would aim to protect globally against pandemic influenza viruses that have not yet evolved. Thus they differ from seasonal vaccines to influenza virus, which are updated annually in spring to incorporate the latest circulating viruses, and are then produced and delivered before the peak influenza season starts in late fall and winter. The efficacy of seasonal vaccines is linked to their ability to induce virus-neutralizing antibodies, which provide subtype-specific protection
\end{abstract}

\section{L.J. DiMenna and H.C.J. Ertl $(\bowtie)$}

The Wistar Institute, 3601 Spruce St, Philadelphia, PA, 19104, USA

e-mail: ertl@wistar.upenn.edu 
against influenza A viruses. If pandemic vaccines were designed to resemble current vaccines in terms of composition and mode of action, they would have to be developed, tested, and mass-produced after the onset of a pandemic, once the causative virus had been identified. The logistic problems of generating a pandemic vaccine from scratch, conducting preclinical testing, and producing billions of doses within a few months for global distribution are enormous and may well be insurmountable. Alternatively, the scientific community could step up efforts to generate a universal vaccine against influenza A viruses that provides broadly cross-reactive protection through the induction of antibodies or $\mathrm{T}$ cells to conserved regions of the virus.

\section{Introduction}

Influenza viruses belong to the family of Orthomyxoviridae, which includes negative single-stranded RNA viruses with segmented genomes. Among the three genera of influenza viruses (A, B, and C), influenza $A$ and $C$ viruses infect humans as well as other species, while influenza B virus mainly infects humans. The most common and serious infections of humans are caused by influenza A virus. Influenza A viruses are further divided into subtypes based on their hemagglutinin (HA) and neuraminidase (NA) genes, which encode the two viral surface proteins.

Influenza A virus typically infects epithelial cells that line the respiratory tract, but may also replicate in other tissues in different hosts, including conjunctiva, intestine, brain, liver, kidney, and gut. In general, influenza A virus infections are self-limiting in healthy human adults, and mainly cause life-threatening disease in the very young and in the elderly. Notwithstanding, this depends on the circulating type. Aquatic birds serve as the main reservoir of influenza A viruses and carry all of the known subtypes (H1-16, N1-9) without necessarily developing disease upon infection. The virus can adapt to other species such as poultry, pigs, horses, or humans. In humans, thus far the $\mathrm{H} 1, \mathrm{H} 2$, or $\mathrm{H} 3$, and $\mathrm{N} 1$ or $\mathrm{N} 2$ influenza viruses have established transmittable infections.

Influenza viruses mutate rapidly, and these mutations affect mainly (but not exclusively) the genes encoding the surface proteins. Point mutations that cause gradual changes are referred to as antigenic drift, and allow the virus to evade protective neutralizing antibody responses induced by previous infections. Most annual epidemics are caused by antigenic drift variants. Rearrangements of the HA- or NA-encoding gene segments between viral types circulating in humans and those endemic in animals result in more dramatic changes, also called antigenic shifts, and the pandemics of 1957 with H2N2 and 1968 with H3N2 were caused by such new types of influenza virus. According to the World Health Organization (WHO), a pandemic is the emergence of a serious new disease caused by an agent that spreads easily among humans. WHO recommends three measures to lessen the impact of the next influenza virus pandemic: (1) increased surveillance to allow for the earliest possible warning that a human pandemic has started; (2) early intervention to stall global spread and prevent further adaptations; and (3) development of an effective pandemic vaccine. 
Available vaccines against influenza virus are seasonal vaccines that are updated annually to incorporate the latest circulating viruses. Seasonal vaccines are composed of three different influenza viruses, which are typically two subtypes of influenza A virus and one strain of influenza B virus. The vaccine composition is generally agreed upon in spring to allow for manufacturing and distribution before onset of the influenza season in late fall to winter. Seasonal vaccines are currently derived from egg-grown viruses that are either inactivated and then given systemically or attenuated by cold adaptation and given directly to the airways.

Pandemic vaccines, the focus of this chapter, are at this stage virtual vaccines of an unknown composition. They aim to protect against a newly evolved pandemic influenza virus. A pandemic vaccine may thus have to be manufactured at the onset of a pandemic, or alternatively one would need to devise a vaccine that induces broadly cross-reactive protection, unlike the current vaccines.

\section{Influenza A Viruses}

Influenza A viruses are enveloped spherical viruses which contain eight segments of single negative-stranded RNA. Segments 1, 2, and 3 encode the transcriptase complex composed of basic polymerases (PB)2 (segment 1) and PB1 (segment 2) and acid polymerase (PA, segment 3). Segment 4 encodes the hemagglutinin (HA), which has receptor-binding activity, promotes cell fusion, and is the major target for neutralizing antibodies. Segment 5 encodes the nucleoprotein (NP) which complexes the viral RNA to form the nucleocapsid. NP is a major target for cross-reactive CD8 ${ }^{+} \mathrm{T}$ cells in mice and humans (Falk et al. 1991). Segment 6 encodes the viral neuraminidase (NA), a cell surface protein with enzymatic activity, which also provides a target for neutralizing antibodies. Drugs such as zanamivir and oseltamivir, which block the enzymatic cleavage of sialic acid residues by NA, are available and can be used to treat or prevent infections (Garman and Laver 2004). Segment 7 encodes matrix (M) protein 1 and 2. M2 has ion channel activity, which is blocked by the antiviral drug amantadine (Ison and Hayden 2001). M protein is also a target for cross-reactive $\mathrm{CD}^{+} \mathrm{T}$ cells in humans, while the M2 ectodomain is a target for nonneutralizing but nevertheless protective antibodies (Zhang et al. 2006). Segment 8 encodes nonstructural proteins (NS) 1 and 2.

\section{Previous Influenza A Virus Pandemics}

The twentieth century experienced three major influenza virus pandemics (Table 1) and several small abortive pandemics, as well as pandemic threats and numerous outbreaks in animals also called epizootics or panzootics. 
Table 1 Recent influenza pandemics

\begin{tabular}{|c|c|c|c|c|}
\hline Pandemic & Subtype & $\begin{array}{l}\text { Place of } \\
\text { origin }\end{array}$ & $\begin{array}{l}\text { Age group most } \\
\text { affected (years) }\end{array}$ & Death toll \\
\hline Spanish Flu 1918-1920 & H1N1 & USA & $20-40$ & 50-100 million \\
\hline Asian Flu 1957-1958 & $\mathrm{H} 2 \mathrm{~N} 2$ & China & $65+$ & $1-4$ million \\
\hline Hong Kong Flu 1968-1969 & $\mathrm{H} 3 \mathrm{~N} 2$ & Hong Kong & $65+$ & 500,000 \\
\hline
\end{tabular}

\subsection{Pandemics}

\subsubsection{Spanish Flu}

The first pandemic of the twentieth century started in 1918 in the USA and then spread to Africa and Europe, first to France and then Spain, and subsequently to every part of the globe. This pandemic was caused by an H1N1 virus and is paradoxically and unfairly referred to as the Spanish Flu. The pandemic that started in March of 1918 and lasted until June of 1920 killed half a million Americans and somewhere between 50 and 100 million humans worldwide (Johnson and Mueller 2002). This virus infected nearly $50 \%$ of the population and killed $2.5 \%$ of all of those that became infected. It is estimated that 25 million people died during the first 25 weeks of the pandemic. Death rates were high in humans between the ages of 20-40, an age group which generally recovers easily from influenza A virus infection. During the initial stages of the pandemic, the early symptoms of infection, which included hemorrhages and lung edema followed by death within $24-48 \mathrm{~h}$, were commonly misdiagnosed. The severity of the symptoms is assumed to have been caused by an excessive release of cytokines in response to the virus (Kash et al. 2004), which was most severe in healthy adults with sturdy immune systems. The $1918 \mathrm{H} 1 \mathrm{~N} 1$ virus was recently isolated from victims preserved in permafrost, and upon sequencing the virus was rederived through genetic engineering (Tumpey et al. 2005). This allowed for an extensive characterization of the virus using modern tools of science. The 1918 H1N1 virus has several distinct features that may explain its unique virulence. Most types of influenza A virus require trypsin-like enzymes for cleavage of the viral HA, which in turn restricts their cellular tropism. The NA of the H1N1 virus of 1918 can directly or indirectly cleave HA, thus rendering this virus independent of trypsin-like enzymes (Steinhauer 1999). Increased virulence was further enabled by NS proteins, which allow the virus to disable the interferon (IFN) pathway (Seo et al. 2004), a crucial component of both innate and adaptive immunity. Human-to-human transmission, a prerequisite for a human pandemic, appears to have involved a switch in preferential binding of the HA protein from $\alpha-2,3$ sialic acid found in the avian enteric tract to $\alpha-2,6$ sialic acid present in the human respiratory tract (Tumpey et al. 2007). This altered receptor binding activity can be achieved experimentally through a single amino acid exchange at position 190 of the HA of the 1918 H1N1 subtype. Additional changes in the viral PB and PB2 proteins, which contain four amino acids that are 
conserved in human viruses and that differ from those prevalent in avians, are likely to have affected transmission between humans (Russell and Webster 2005).

\subsubsection{Asian Flu}

The 1957 pandemic, also referred to as the Asian Flu, originated from a recombination between a circulating human virus and a virus endemic in ducks. The virus was first isolated early in 1956 in Guizhou, China, and by February of 1957 had spread to Singapore, and to the USA by June of that year. This virus, an H2N2 virus, caused an estimated 1-4 million deaths worldwide (Dunn 1958). Death rates were highest in the elderly.

\subsubsection{Hong Kong Flu}

The 1968 pandemic, also called the Hong Kong Flu, was caused by an antigenic shift of an $\mathrm{H} 2 \mathrm{~N} 2$ virus to an $\mathrm{H} 3 \mathrm{~N} 2$ virus. This pandemic was comparatively mild, causing an estimated 500,000 human deaths (Cockburn et al. 1969; Kilbourne 2006). Again mortality was high in those above 65 years of age.

\subsection{Pseudopandemics and Abortive Pandemics}

In 1946 an H1N1 virus that was first seen in Japan and Korea spread to military bases in the USA (Lessler et al. 2007). Further spread was not observed. In 1977, an $\mathrm{H} 1 \mathrm{~N} 1$ virus spread rapidly from China and caused epidemic disease in children and young adults ( $<23$ years) worldwide. Older humans were not affected, presumably due to protection from previous exposure to H1N1 viruses.

\subsection{Pandemic Threats}

\subsubsection{Swine Flu}

In the winter of 1976, a novel swine influenza virus subtype was detected in military recruits at Fort Dix, New Jersey. A total of 13 soldiers became symptomatically infected and one died. There was only limited spread to humans living outside the military base. Fearing a major pandemic, a vaccine was rapidly generated and administered to 40 million humans. A few months after mass vaccination had started, reports of Guillain-Barré syndrome in vaccine recipients started to accumulate, and by early 1977 (when vaccination was stopped) more than 500 cases of GBS had been reported, 25 of which were fatal (Langmuir et al. 1984). 


\subsubsection{Bird Flu}

A highly pathogenic form of avian H5N1 virus was first detected in Asian poultry in 1997 (Centers for Disease Control and Prevention 1997). During this year, a total of 18 human cases were reported from Hong Kong, of which six were fatal. The virus rapidly caused pneumonia and multiple organ failure in infected individuals, which were mainly young adults. Culling of infected flocks of poultry initially appeared to have stopped further spread, but then in 2003 additional human cases with a similar H5N1 virus were recorded in Vietnam (Tran et al. 2004). As of January of 2008, 349 human cases of H5N1 virus infection with 216 deaths have been reported from Asia, Eurasia, and North Africa. ${ }^{1}$ Most cases occurred in Indonesia, Vietnam, and Egypt. Highly pathogenic H5N1 virus was also isolated from poultry and wild birds in Europe, including the United Kingdom. Thus far, the virus has been transmitted by human contact with infected birds, and only a few isolated cases were suggestive of direct human-to-human transmission. Further mutations of $\mathrm{H} 5 \mathrm{~N} 1$ virus, either in the form of adaptive point mutations (i.e., antigenic shift) or through reassortment in humans concomitantly infected with a different influenza A virus, could eventually allow for sustained and efficient human-to-human transmission. Control measures have focused on culling of infected flocks of domestic birds and restriction of poultry trade between countries. Some countries implemented vaccination programs for poultry (Steel et al. 2008; Cristalli and Capua 2007). Other countries rejected the idea of bird vaccination due to fears that this may mask infections and allow for further mutations that may promote human transmissibility.

Similar to the 1918 H1N1 virus, pathogenic H5N1 virus activates HA through a trypsin-independent mechanism (Hulse et al. 2004). Pathogenic H5N1 virus has a multibasic cleavage site that can be digested by furin and furin-like proteases, which are more ubiquitously present in human tissues than the trypsin-like enzymes that cleave HA of current human influenza viruses. The NS1 protein of pathogenic subtypes of $\mathrm{H} 5 \mathrm{~N} 1$ virus renders the virus resistant to the activity of IFNs and tumor necrosis factor (TNF)- $\alpha$ (Seo et al. 2002). The H5N1 virus has changed since its first isolation in 1997. Such changes include resistance to the antiviral drug amantadine due to a M2 mutation first reported in 2004 from Thailand (Cheung et al. 2006). The virus has become more lethal for humans and mice, and has gained robustness against destruction in the environment. The virus has increased its host range and has been shown to cause disease in felines such as tigers (Keawcharoen et al. 2004), which are otherwise resistant to influenza A virus infections.

In 1999, an H9N2 virus, which also originated from poultry, caused illnesses in two children in Hong Kong. Both children survived and there was no serological evidence that the virus spread to their contacts.

${ }^{1}$ See http://www.who.int/csr/disease/avian_influenza/country/cases_table_2008_01_21/en/index.html. 


\subsection{Epizootics and Panzootics}

A number of epizootics and panzootics have been caused by a wide variety of influenza viruses. In poultry, numerous outbreaks with highly pathogenic influenza viruses have been reported from all over the globe within the last 50 years. These outbreaks were caused by a variety of subtypes, such as H5N1, H7N2, H1N7, H7N3, H13N6, H5N9, H11N6, H3N8, H9N2, H5N2, H4N8, H10N7, H2N2, H8N4, H14N5, H6N5, H12N5, and others. H5N1 virus, which is currently endemic in Asia, Africa, and Europe, has within the last eight years caused the deaths of millions of birds, many of which were culled to prevent further spread and to protect humans.

Influenza virus outbreaks have been observed in other species. For example, from 1979 to 1980, several hundred harbor seals died along the coast of New England due to infection with a H7N7 virus (Geraci et al. 1982). As of 1997, H3N2 circulates in pigs (Gramer et al. 2007). Horses have been infected with H7N7 and H3N8 viruses (Amonsin et al. 2007; Oxburgh and Hagström 1999). The latter can also infect and kill canines. H5N1 has caused the deaths of felines, including tigers and domestic cats (Cristalli and Capua 2007; Steel et al. 2008).

Several of these viruses have infected humans without achieving the capacity for human-to-human transmission. In 2003, 89 people were infected with H7N7 influenza virus from poultry in the Netherlands (Koopmans et al. 2004).

In 2002-2003, two residents of US mid-Atlantic states showed serologic evidence of infection with H7N2 (Senne et al. 2006). In 2004, two poultry farm workers in British Colombia became infected with H7N3 virus (Tweed et al. 2004). In 2004, Egypt reported human infections with H10N7. Any subtype of the influenza virus thus has the potential to infect humans and to evolve into a pandemic virus, which has to be taken into account when designing pandemic vaccines.

\section{Risk Factors for Severe Influenza Virus Infections}

More than $90 \%$ of deaths during seasonal influenza virus outbreaks occur in the elderly ( $\geq 65$ years of age). Immunosenescence during aging leads to impaired immune responses, which increases the susceptibility of the aged to infectious agents. The elderly are affected by primary immunological changes, which are part of the natural aging process, and secondary immunological changes caused by underlying diseases and unhealthy life styles (Malaguarnera et al. 2001). Primary changes of the immune system in healthy elderly involve mainly $\mathrm{T}$ cells, though changes in natural killer (NK) cells and NK T cell function with age have been noted (Ginaldi et al. 1999c; Solana and Mariani 2000). T cells show clonal senescence, their potential for expansion is decreased, and their ability to produce certain cytokines and to respond to cytokines decreases. The proportion of $\mathrm{T}$ cells with a memory cell phenotype increases while numbers of naïve $\mathrm{T}$ cells decrease. Stimulation with new antigens appears to result in shortened immunological memory (Ginaldi et al. 1999b). The T cell repertoire loses diversity (Effros et al. 2003) due 
to chronic antigenic stimulation, leading to continued clonal expansion of some $\mathrm{T}$ cells, which undermines the homeostatic balance of the immune system. Primary B cell responses in the elderly are commonly low and short-lived, resulting in antibodies with low affinity (Ginaldi et al. 1999a). Formation of germinal centers is decreased, antigen transport is impaired, and follicular dendritic cells show atrophy and their capacity to form antigen depots is reduced (Zheng et al. 1997; Aydar et al. 2004). Autoantibodies are more common and the B cell repertoire becomes more restricted. Many of these changes reflect secondary effects due to an age-related decline of helper functions from $\mathrm{CD}^{+} \mathrm{T}$ cells, which show reduced expression of critical costimulatory receptors that are essential for activation of B cells, germinal center formation and rearrangement, and hypermutation of immunoglobulin genes. Underlying chronic diseases dramatically increase the risk of serious complications of an influenza virus infection. Patients with one or two chronic diseases have 40or 150-fold (respectively) greater risk for developing pneumonia upon influenza virus infection (Janssens and Krause 2004; Stott et al. 2001). Underlying chronic heart, lung, or liver diseases increase the risk of serious influenza virus infection in all age groups, not just the elderly.

Vaccines perform poorly in the elderly, commonly resulting in inadequate and short-lived titers of protective antibody responses (Biro 1978; Saurwein-Teissl et al. 2002). Current influenza virus vaccines provide $70-90 \%$ protection against a closely related virus in those $<65$ years of age, but only $30-40 \%$ protection in humans above the age of 65 .

Young children, pregnant women, and immunosuppressed individuals also have an increased risk for influenza A virus-associated morbidity. Another risk factor is superinfection of the airways with bacterial pathogens, which can enhance virulence of the influenza virus through bacterial proteases (Callan et al. 1997). On the other hand, influenza virus can increase bacterial infection by destroying respiratory epithelium and increasing bacterial receptor (McCullers 2006). Other risk factors include living in institutionalized settings such as prisons or nursing homes, or working in healthcare, where the risk of exposure and the risk of further spread are increased.

\section{Immune Responses to Influenza A Viruses}

Vaccines aim to induce memory immune responses that, upon encountering the virus, are rapidly reactivated or recruited to either completely prevent an infection by causing so-called sterilizing immunity, or to rapidly control viral spread. It is thus important to understand which type of immune response provides reliable protection in order to specifically design immunogens that elicit this type of a response. Influenza virus pandemics unfortunately have an element of surprise on their side by their very nature, and it may be unrealistic to expect that at the onset of a pandemic, which can potentially spread around the globe within less than six months, sufficient doses of a reliable vaccine or efficacious antiviral drugs will 
be available to protect the entire human population. Other preventions, such as activation of protective innate immune responses in those at immediate risk for infection, may add to the repertoire we can call upon to combat the next influenza virus pandemic.

\subsection{Innate Immunity}

Innate immunity can provide resistance to influenza virus infection, as has been demonstrated in animals treated with immunomodulators such as baculovirus, lentidan, double-stranded RNA, or modified heat-labile toxin of Escherichia coli prior to infection (Abe et al. 2003; Irinoda et al. 1992; Saravolac et al. 2001; Williams et al. 2004). Clinical trials in children who were vaccinated with an attenuated influenza A virus vaccine after the onset of an influenza A virus outbreak also suggested that protection was at least in part mediated by an innate immune response to the vaccine (Piedra et al. 2007).

Influenza A virus infection leads to the rapid increase of proinflammatory cytokines in nasal and pulmonary secretions (Jao et al. 1970; Gentile et al. 1998). The virus causes the activation and maturation of dendritic cells and stimulates plasmacytoid dendritic cells to secrete large amounts of type I IFNs (López et al. 2004; Cella et al. 2000). Influenza virus activates macrophages to secrete IL-1, 6 and 12 and TNF- $\alpha$ (Mak et al. 1982; Pirhonen et al. 1999). IL-12 in turn induces IFN- $\gamma$ production by NK cells. The early cytokine response to influenza virus can be pronounced and can result in significant pathology (Van Reeth et al. 2002).

Nevertheless, early cytokines such as interferons also provide resistance to influenza A viruses (Beilharz et al. 2007; Fattal-German and Bizzini 1992). NS1 of H5N1 renders the virus resistant to the antiviral activity of IFNs and TNF- $\alpha$ (Sekellick et al. 2000). Reassortant influenza A viruses carrying the NS1 of H5N1 induce increased levels of cytokines in mice and decreased levels of IL-10 (Lipatov et al. 2005a). Both macrophages and NK cells can kill infected cells and are crucial to early infection control (Zychlinsky et al. 1990; Tsuru et al. 1987), as are natural $\operatorname{IgM}$ and the early components of the classical pathway of complement, which together can neutralize influenza virus (Jayasekera et al. 2007).

\subsection{Primary Adaptive Immune Responses to Influenza Virus Infection}

Inhalation infection with influenza A virus triggers a mucosal immune response in the upper respiratory tract that is initiated within nasal-associated lymphoid tissue (NALT) in mice and within Waldeyer's ring (tonsils) in primates. In the lower respiratory tract, responses are induced in bronchus-associated lymphoid tissues. Responses can also be detected in distant lymphoid tissues such as spleen or blood. 
Infection causes a local secretory $\operatorname{IgA}$ response as well as $\operatorname{IgM}$ and $\operatorname{IgG}$ antibodies directed mainly against the viral HA. Antibody-secreting cells can be detected in mice in the respiratory mucosa and in lung tissue within five days after infection. Dimeric IgA (dIgA) antibodies which are transcytosed across epithelial cells upon binding to their receptors can bind to de novo synthesized viral antigens and block viral assembly, thus contributing to viral clearance (Tamura and Kurata 2004).

Influenza virus-specific $\mathrm{CD}^{+}$and $\mathrm{CD}^{+} \mathrm{T}$ cells are induced upon intranasal application of influenza A virus (Roti et al. 2008; Swain et al. 2004). Viral clearance following a primary infection is mediated in part by $\mathrm{CD}^{+} \mathrm{T}$ cells and in part by antibodies, which in turn require the activity of $\mathrm{CD}^{+} \mathrm{T}$ helper cells for their induction. Lack of $\mathrm{CD}^{+} \mathrm{T}$ cells does not affect induction of a primary $\mathrm{CD}^{+} \mathrm{T}$ cell response to influenza A virus (Yap and Ada 1978; Mozdzanowska et al. 2005), although absence of $\mathrm{CD}^{+} \mathrm{T}$ cells in general reduces the magnitude of the memory $\mathrm{CD}^{+} \mathrm{T}$ cell pool and the $\mathrm{CD}^{+} \mathrm{T}$ cell recall response. Neither IFN- $\gamma$ nor IFN- $\alpha / \beta$ appear to be essential for viral clearance (Price et al. 2000), although loss of both IFN pathways has been reported to exacerbate disease. Perforin is essential for viral clearance, and mice lacking perforin show delayed viral clearance and increased mortality to influenza A virus infection (Topham et al. 1997). Increased mortality was also observed in IL-1 receptor knockout mice (Szretter et al. 2007); these mice developed normal $\mathrm{CD}^{+} \mathrm{T}$ cell responses and viral titers were only modestly above those of normal mice. IL-1 receptor knockout mice showed a defect in recruitment of inflammatory cells to the site of infection, most notably neutrophils and $\mathrm{CD} 4^{+} \mathrm{T}$ cells.

\subsection{Secondary Adaptive Immune Responses and Their Role in Protecting Against Infection}

A secondary infection with influenza A virus can be prevented by local sIgA and can be blunted by rapid activation of memory B cells. Neutralizing IgA antibodies are thought to primarily prevent infection of the upper respiratory tract, while serum IgG plays a role in protecting against viral pneumonia (Tamura and Kurata 2004). Protective neutralizing antibody responses induced by infection or vaccination are subtype specific and do not provide protection against heterotypic challenge. Their ability to provide resistance to an antigenic drift subtype depends on the degree of antigenic variation between the viruses (Kaye et al. 1969).

It must pointed out, however, that although the role of neutralizing antibodies in providing resistance to influenza virus is not debated, it remains far from clear-cut. Some mouse studies showed that adaptive transfer of neutralizing secretory IgA protected the animals, while transfer of neutralizing antibodies of the IgG isotype was inefficient (Renegar and Small 1991). Other mouse studies showed that protection by H5-specific IgG1 monoclonal antibodies can be achieved against H5N1 infections (Hanson et al. 2006). Yet others reported protection by IgG antibodies that bound HA but failed to neutralize the virus (McLain and Dimmock 1989). One monoclonal neutralizing antibody was described that cross-reacted between $\mathrm{H} 1$ and 
$\mathrm{H} 2$ and consequently protected animals upon passive transfer against infection with either virus (Okuno et al. 1994). In other virus infections, such as those with rabies virus, where neutralizing antibodies are known to play a dominant role in protection against infection and disease, protective titers of neutralizing antibodies have been defined. For rabies virus, a titer of or above 0.5 international units protects against challenge; this knowledge has greatly facilitated vaccination efforts. In contrast, it is still not known what titer of influenza A virus-neutralizing antibodies reliably provides protection against disease. In general, it is assumed that titers above 1:40 are protective, although numerous clinical trials have demonstrated that humans with lower titers were protected while others with higher titers developed symptomatic infections.

Protection against heterotypic challenge (i.e., challenge with a different subtype of influenza virus than that used for immunization) can be mediated by a number of mechanisms. As already mentioned above, some neutralizing antibodies can cross-neutralize several subtypes of influenza A virus. Nonneutralizing antibodies to the ectodomain of matrix protein (M2e) can protect against heterotypic challenge in animal models (Mozdzanowska et al. 2003). The 23 amino acid (aa) long M2e is conserved in its nine $\mathrm{N}$-terminal amino acids and shows relative minor variability in the remaining sequences. This is likely to reflect a lack of selective pressure, as natural infections or traditional vaccines induce only low antibody responses to M2e (Feng et al. 2006). The currently circulating avian H5N1 and H7N2 subtypes show sequence variability with previous human isolates that affect M2e antibodybinding sites. For example, they show changes in amino acids at positions 10-16 of M2e (H5N1: PIRNEWG to PTRNGWG, or PTRNEWE) (Liu et al. 2005).

$\mathrm{CD}^{+} \mathrm{T}$ cells induced by repeated infections appear to contribute little to natural resistance to influenza virus infection in humans. This may be linked to suboptimal stimulation of this $\mathrm{T}$ cell subset upon natural infection, as human volunteers with exceptionally high levels of circulating influenza A virus-specific $\mathrm{CD}^{+} \mathrm{T}$ cells showed reduced viral shedding upon an experimental infection compared to those with low levels of pre-existing influenza A virus-specific $\mathrm{CD}^{+} \mathrm{T}$ cells (Epstein 2006; Murasko et al. 2002).

In mice, a number of studies showed that $\mathrm{CD} 8^{+} \mathrm{T}$ cells protect, while other showed that they fail to protect. Early studies from the group of G. Ada showed that adoptive transfer of influenza virus immune cells provided protection against challenge with a heterotypic subtype of the virus (Yap and Ada 1978). These studies were confirmed by R. Dutton and colleagues, who studied the efficacy of passively transferred, in vitro activated $\mathrm{CD}^{+} \mathrm{T}$ cells isolated from mice transgenic $(\mathrm{tg})$ for a T cell receptor (TcR) to the influenza A virus HA (Cerwenka et al. 1999). Transfer of naïve TcR-tg CD8 ${ }^{+} \mathrm{T}$ cells failed to provide resistance to challenge. Protection against a lethal infection could be provided by the transfer of rested memory-like or effector TcR-tg CD8 ${ }^{+} \mathrm{T}$ cells, although the latter effected more rapid viral clearance, which may indicate that the rested $\mathrm{CD}^{+} \mathrm{T}$ cells needed to expand before they assumed effector functions. Protection was only mediated by $\mathrm{CD}^{+} \mathrm{T}$ cells that were able to home to the infected respiratory tissues. Poxvirus vectors expressing the influenza A virus NP, which induce a $\mathrm{CD}^{+} \mathrm{T}$ cell response (Andrew et al. 1986), 
were shown to induce some protection against heterotypic challenge (Endo et al. 1991; Altstein et al. 2006). Further studies showed that although vaccinia virus vectors expressing the influenza virus NP induced only limited protection in mice, adoptive transfer of $\mathrm{T}$ cells isolated from NP-immune mice and expanded in vitro were highly effective (Mbawuike et al. 2007). Yet another group reported that a vaccinia virus vector which expressed a sequence of NP that induced a sturdy CD8 ${ }^{+}$ $\mathrm{T}$ cell response in mice, including in their lungs, completely failed to induce protective immunity as assessed by peak viral loads, morbidity or mortality (Lawson et al. 1994).

Heterotypic $\mathrm{T}$ cell-mediated protection was also reported after immunization of mice with an adjuvanted influenza virus vaccine (Sambhara et al. 1998) or with DNA vaccines expressing internal proteins of influenza virus (Saha et al. 2006; Fu et al. 1997). Another group reported that protection upon intranasal immunization with an adjuvanted nucleoprotein vaccine was mediated by $\mathrm{T}$ helper cells of the Th1 type rather than by CD8 ${ }^{+} \mathrm{T}$ cells (Tamura et al. 1996). Yet another group reported protection with an adenovirus vector expressing nucleoprotein (Roy et al. 2007). In our hands, subunit vaccines expressing the nucleoprotein induced strong $\mathrm{CD}^{+} \mathrm{T}$ cell responses that could readily be detected in spleen, blood, or even lungs of vaccinated mice. Nevertheless, vaccinated mice were not reliably protected against disease or death following challenge with influenza A virus (unpublished). Overall $\mathrm{T}$ cell protection studies largely agree that adoptive transfer of in vitro expanded $\mathrm{CD}^{+} \mathrm{T}$ cells provides protection against influenza virus. Results on the protective nature of in situ activated influenza virus-specific $\mathrm{CD} 8^{+} \mathrm{T}$ cells range from solid protection to complete absence of protection, even under circumstances where high numbers of influenza virus-specific $\mathrm{CD} 8^{+} \mathrm{T}$ cells were present in the airways at the time of challenge. The lack of consistency of protection through $\mathrm{CD}^{+} \mathrm{T}$ cells may reflect genetic differences in the mouse strain used for the experiments, differences in the dose or type of challenge virus, differences in the interval between vaccination and challenge, and/or differences in the functionality of CD8 ${ }^{+}$ $\mathrm{T}$ cells induced by various approaches.

The take-home message for developing an influenza vaccine that is useful for preventing or ameliorating a pandemic therefore remains ambiguous. Neutralizing antibodies protect against HA provided there is sufficient homology between the vaccine and the infecting virus. Antibodies against M2e protect against a wider array of subtypes, as M2e is more conserved; nevertheless, M2e shows some variability, and protection through M2e-specific antibodies is not as robust as protection provided by neutralizing antibodies. The rules that govern $\mathrm{CD}^{+} \mathrm{T}$ cell-mediated protection against influenza virus remain ill-defined.

\section{Influenza Virus Vaccines}

Influenza virus was first isolated in 1933 (Smith et al. 1933), and effective vaccines were developed and tested by 1943-1944 and became available by 1945 (Francis et al. 1945a,b). Vaccines were thus not available during the Spanish Flu pandemic, 
but rapidly became available during the 1957 Asian Flu pandemic (Gundlefinger et al. 1958), when they were mainly used in military personnel. Although the 1968 Hong Kong Flu subtype was identified rapidly, vaccine production was delayed, and a vaccine was not available during the outbreak.

Until recently, all available influenza vaccines were trivalent inactivated (killed) virus vaccines. Initially whole-virus vaccines were used, which were then replaced by 2001 by the less reactogenic split-virus vaccines. In June of 2003, a live attenuated, cold-adapted, temperature-sensitive, trivalent influenza virus vaccine was licensed in the United States for use in humans between 2 and 49 years of age. Multiple clinical trials have been performed in adults (Demicheli et al. 2004), children (Smith et al. 2006), and the elderly (Jefferson et al. 2005) to assess the efficacy of influenza vaccines. Studies on live vaccines are still limited, but to date they suggest that such vaccines may be more effective than inactivated vaccines in some cohorts (Treanor et al. 1999).

One manuscript published an analysis of trials involving a total of 59,566 adults (Demicheli et al. 2004) which showed that the live attenuated vaccines reduced the number of cases of serologically confirmed influenza by $48 \%$ while the inactivated vaccines had a vaccine efficacy of $70 \%$. The yearly recommended vaccines had low effectiveness against clinical influenza cases or time off work, the later a nonspecific outcome that included illness caused by influenza as well as other agents. The authors concluded that universal immunization of healthy adults is not supported by their results.

Fifty-one studies involving 263,987 children were included in an analysis of influenza virus vaccine efficacy in children (Smith et al. 2006). The attenuated vaccines showed an efficacy of $79 \%$ in children older than two years, while inactivated vaccines had a lower efficacy of 59\%. In children under two, the efficacy of inactivated vaccine was similar to placebo. In another study, results from 19 randomized clinical studies covering a total of 247,517 children were analyzed and reported to show an overall vaccination efficacy of $36 \%$ against clinical disease, $67 \%$ against laboratoryconfirmed cases, and $51 \%$ against acute otitis media. Between-study variability was related to the children's age and study quality. For example, when studies from the USSR were excluded from the analysis, the overall efficacy of the vaccine in preventing clinical cases increased from 36\% to 61\% (Manzoli et al. 2007).

Indirect evidence for the effectiveness of annual influenza virus vaccination of children can be gained from Japan, where as of 1957 school children were vaccinated annually. Vaccination became mandatory in the 1970s and was discontinued in 1994. During the time of mandatory vaccination, mortality among the elderly declined markedly, presumably due to reduced exposure to their infected grandchildren.

Sixty-four studies were analyzed to determine the efficacy of influenza vaccination in the elderly (Jefferson et al. 2005; Rivetti et al. 2006). In homes for elderly individuals, the effectiveness of vaccines against disease caused by influenza virus could not be demonstrated. When the vaccines were closely matched to the circulating virus subtype, they prevented pneumonia, hospital admission, and deaths. In elderly individuals living in the community, vaccines were not significantly effective against clinical influenza or pneumonia that were not laboratory confirmed. The authors concluded that vaccination was useful in long-term care facilities but not 
necessarily in community settings. Another large analysis of community-living elderly came to the opposite conclusion. This analysis showed that vaccination was associated with a $27 \%$ reduction in the risk of hospitalization for pneumonia and a $48 \%$ reduction in the risk of death (Nichol et al. 2007). Other smaller studies showed that immunization of frail elderly did not reduce the rate of hospital admissions due to acute respiratory illnesses (Jordan et al. 2006), and that vaccination failed to reduce the overall mortality of the elderly (Rizzo et al. 2007).

In summary, although annual influenza virus vaccination is highly recommended, especially for high-risk populations, results of clinical trials designed to prove their efficacy remain controversial and thus far do not fully support the notion that vaccination affords reliable protection against influenza virus infection and its sequelae.

\section{Pandemic Influenza Virus Vaccines}

WHO has summarized a number of global pandemic phases that have been adopted in federal and regional response plans and serve to define the type of responses required. Details on these phases and suggested courses of action can be obtained online (see also Table 2). ${ }^{2}$ These phases are as follows:

A. Interpandemic period: Phase I: No new influenza virus subtypes have been detected in humans but they may be present in animals. Risk of human infection is considered low. Phase II: An influenza virus subtype circulating in animals poses a high risk to humans.

B. Pandemic alert period: Phase III: Animal-to-human infection(s) with a new subtype, Phase IV: Small and localized cluster(s) with limited human-to-human transmission; Phase $V$ : Larger but still localized cluster(s) of human-to-human transmission.

C. Pandemic period: Phase VI: Increased and sustained human-to-human transmission.

D. Postpandemic period.

As of early 2008, the USA is currently in an interpandemic period, while parts of Asia, Africa, and Eurasia have entered Phase III(/IV) of a pandemic alert period; pathogenic avian H5N1 virus has repeatedly infected humans without causing proven human-to-human transmission yet. Small clusters of human infections that may reflect human-to-human transmission have been observed.

In anticipation of an influenza virus pandemic that would kill up to an estimated 1.9 million Americans and require the hospitalization of an estimated 10 million Americans, in November of 2005 the Department of Health and Human Services issued a pandemic influenza plan, ${ }^{3}$ and State Governments developed blueprints for

\footnotetext{
${ }^{2}$ See http://www.who.int/csr/disease/avian_influenza/phase/en/index.html

${ }^{3}$ See http://www.hhs.gov/pandemicflu/plan/overview.html\#es.
} 
Table 2 WHO pandemic classifications

\begin{tabular}{|c|c|c|}
\hline \multirow[t]{2}{*}{ Interpandemic period } & Phase I & $\begin{array}{l}\text { Novel influenza subtypes present in animals. Low risk } \\
\text { of human infection }\end{array}$ \\
\hline & Phase II & Humans at high risk of animal subtype \\
\hline \multirow[t]{3}{*}{ Pandemic alert period } & Phase III & $\begin{array}{l}\text { Animal-to-human transmission of a novel influenza } \\
\text { subtype }\end{array}$ \\
\hline & Phase IV & Small clusters of human-to-human transmission \\
\hline & Phase V & $\begin{array}{l}\text { Larger contained clusters with human-to-human } \\
\text { transmission }\end{array}$ \\
\hline Pandemic period & Phase VI & $\begin{array}{l}\text { Human-to-human transmission of virus is sustained } \\
\text { and spreading }\end{array}$ \\
\hline Postpandemic period & & Threat of human-to-human transmission has subsided \\
\hline
\end{tabular}

local pandemic response plans. Funding was provided to increase infrastructure, enhance vaccine production capability, and to augment basic knowledge on influenza virus pathogenesis and host responses.

How much experience do we have with pandemic influenza virus vaccines? As mentioned above, vaccines for the Spanish and Hong Kong Flu pandemic were not available at that time, and the vaccine that was available during the Asian Flu pandemic was mainly used in military personnel (Dull et al. 1960). In summary, our experience with the global use of a vaccine for pandemic influenza virus is nonexistent. One could envision four scenarios for the role of a vaccine in the next influenza virus pandemic: (a) an ideal outcome in which the world could be vaccinated with a universal vaccine that would never allow another pandemic to strike, (b) an optimistic outlook in which sufficient doses of a vaccine are produced in advance in order to rapidly immunize those at the epicenter of the pandemic and those at high risk, before additional vaccine for global immunization could be produced and distributed, (c) a pragmatic attitude that prepares as effectively as possible for the next pandemic without necessarily expecting that a vaccine will be on hand at the start of the pandemic, and (d) a worst-case scenario, in which the next pandemic influenza virus will outsmart us.

\subsection{Ideal Outcome: Universal Vaccine for Influenza Virus}

In an ideal scenario, scientists would develop a universal vaccine for influenza virus, industry would rapidly get involved in conducting large-scale trials needed for licensure, and then, with the aid of governments and philanthropic agencies, initiate a worldwide vaccination program before the next pandemic subtype of influenza virus evolves. Ideally, the vaccine would be adjuvanted to induce robust, long-lasting immunity not only in healthy adults but also in high-risk populations such as the elderly, infants, or those suffering from chronic diseases. It is hoped such a vaccine would prevent the development of any future influenza virus pandemics (Table 3). 
Table 3 Influenza vaccines

\begin{tabular}{|c|c|c|c|}
\hline Vaccine & Type vaccine & Antigen & Correlate of protection \\
\hline \multirow[t]{3}{*}{ Pandemic } & Inactivated influenza virus & All viral proteins & Neutralizing antibodies \\
\hline & Attenuated influenza virus & All viral proteins & $\begin{array}{l}\text { Neutralizing antibodies, } \mathrm{T} \text { cells } \\
\quad(?)\end{array}$ \\
\hline & $\begin{array}{c}\text { Subunit (viral vectors, } \\
\text { DNA vaccines) }\end{array}$ & HA & Neutralizing antibodies \\
\hline \multirow[t]{2}{*}{ Prepandemic } & $\begin{array}{l}\text { Subunit (viral vectors, } \\
\text { DNA vaccines, fusion } \\
\text { proteins, peptides) }\end{array}$ & M2e & Nonneutralizing antibodies \\
\hline & $\begin{array}{l}\text { Subunit (viral vectors, } \\
\text { DNA vaccines) }\end{array}$ & NP, M & $\mathrm{T}$ cells \\
\hline
\end{tabular}

In experimental animals, some vaccines affect protection against heterotypic challenge with influenza virus, such as vaccines based on M2e (Mozdzanowska et al. 2003; Liu et al. 2004; Slepushkin et al. 1995; Fan et al. 2004; Frace et al. 1999; Neirynck et al. 1999; De Filette et al. 2006; EurekAlert 2007). Protection through M2e-expressing vaccines is mediated by humoral immunity and can be achieved by passive transfer of monoclonal M2e-specific antibodies prior to virus challenge (Mozdzanowska et al. 2003). One vaccine developed by W. Gerhard and colleagues was based on an M2e peptide linked to universal T helper cell epitopes. Others developed M2e vaccines based on papilloma virus-like particles (Ginaldi et al. 1999a), or fusion proteins linking M2e to hepatitis B virus core protein (De Filette et al. 2006). All of these subunit vaccines elicited antibodies to M2e in animals that protected against subsequent challenge with different types of influenza A virus, and the M2e-hepatitis B virus core fusion protein vaccine has now entered a phase I trial (EurekAlert 2007). The immunogenicity of an M2e vaccine could be increased by adjuvants such as Toll-like receptor 5 ligands (Huleatt et al. 2008). In one study, passively immunized animals were challenged with influenza A viruses that were identical or that differed in their M2e sequence; animals were protected against viruses that expressed the same M2e sequence but not against subtypes with M2e variants, (Fan et al. 2004). Several M2e sequences corresponding to the H1N1, H5N1, and H9N2 influenza subtypes were formulated using a liposome-based vaccine technology and evaluated as potential immunogens for the development of a "universal" influenza vaccine. Mice immunized with the polyvalent liposomal M2e survived challenges with different subtypes of influenza virus, and antiserum from immunized mice provided passive protection to naïve mice (Ernst et al. 2006). One study on a DNA vaccine expressing M2e fused to the nucleoprotein of influenza A virus reported increased mortality in vaccinated pigs, indicating that a poorly immunogenic vaccine (and DNA vaccines are commonly poorly immunogenic, especially in larger species) may exacerbate influenza virus-associated pathology (Heinen et al. 2002). In most studies, vaccines expressed one sequence of M2e. Notwithstanding, although M2e is far less variable than HA, it is not completely conserved, and mutants such as those present in recent $\mathrm{H} 5 \mathrm{~N} 1$ variants have been observed, suggesting that a universal M2e-based vaccine for influenza A virus should incorporate several common variants of M2e, including those that are present 
in the currently circulating pathogenic H5N1 viruses (Aydar et al. 2004). M2e vaccines induce some protective immunity, although this protection wanes against high challenge doses of virulent virus. M2e vaccines thus need to be optimized further, either through the use of novel adjuvants, or by their incorporation into more immunogenic vaccine carriers. Once this is achieved, M2e vaccines may well become part of an ideal universal vaccine for influenza virus, alleviating the need for a pandemic vaccine.

Under some circumstances, $\mathrm{CD} 8^{+} \mathrm{T}$ cells directed against conserved sequences of influenza A virus provide protection against heterotypic challenge; however, under other circumstances, they fail to protect. Influenza virus antigens such as NP and $\mathrm{M}$ proteins (which carry conserved epitopes of influenza A virus) and vaccine carriers that induce robust $\mathrm{CD} 8^{+} \mathrm{T}$ cell responses to such epitopes are readily available - the missing link remains a solid knowledge of what distinguishes a protective $\mathrm{CD}^{+} \mathrm{T}$ cell from one that is ineffective or, even worse, exacerbates disease. Once this knowledge is gained, a universal influenza vaccine based on antigens that aim to induce $\mathrm{T}$ cell responses could be developed and deployed, either alone or in combination with an M2e-expressing vaccine.

Currently there is no universal vaccine for influenza virus in the industrial pipeline, and WHO estimates that it will take at least another 5-10 years before such vaccines become available. ${ }^{4}$

\subsection{Optimistic Outlook: Prepandemic Vaccines}

The highly pathogenic H5N1 virus that is endemic in wild birds in Asia, Africa, and Europe, and has spread to poultry and from there to humans, is currently viewed as a major candidate to evolve into the next pandemic subtype, through mutations that allow for efficient human-to-human transmission. Several entities have started to develop vaccines based on current subtypes of avian influenza virus under (a) the assumption that $\mathrm{H} 5 \mathrm{~N} 1$ would evolve into a pandemic virus, and (b) the optimistic conjecture that the pandemic virus would have sufficient homology with currently circulating viruses to allow for cross-protective immunity (Table 3).

The Asian highly pathogenic avian $\mathrm{H} 5 \mathrm{~N} 1$ virus has divided into two antigenic clades. Clade 1 includes human and bird isolates from Vietnam, Thailand, and Cambodia and bird isolates from Laos and Malaysia. Clade 2 viruses include bird isolates from China, Indonesia, Japan, South Korea, the Middle East, Europe and Africa, and were primarily responsible for human H5N1 infections during 2005-2006. Clade 2 is further subdivided into six subclades with a distinct geographic distribution. Over time, the pool of H5N1 viruses that could potentially evolve into a pandemic form is diversifying rapidly, making it very difficult to decide on a specific virus as the basis for a vaccine.

\footnotetext{
${ }^{4}$ See http://www.who.int/immunization/newsroom/PI_QAs/en/index.html.
} 
Initial vaccines were developed for protection against the H5N1 subtype that was isolated from humans in Hong Kong in February 2003, but this virus has changed substantially, so these vaccines are now most likely no longer useful (Suguitan et al. 2006). In April 2004, WHO made a H5N1 prototype seed virus available to manufacturers. In August 2006, WHO changed the prototype and now offers three new prototype viruses. Future changes of the reference virus to accommodate additional mutations are expected.

Developing vaccines to H5N1 based on traditional approaches was a challenging task. The highly virulent H5N1 viruses rapidly kill embryonated chicken eggs, which are used to propagate the influenza A viruses for the annual vaccines. A number of manufacturers thus started to develop cell culture systems based for example on Vero or MDCK cells to propagate H5N1 influenza virus. Cell-grown influenza virus vaccines were tested in humans and showed immunogenicity and safety profiles that were comparable to those of egg-grown vaccines (Halperin et al. 2002). Others used reverse genetics to develop reassortant viruses in which gene segments encoding HA and NA were derived from highly pathogenic H5N1 virus, and all other genes were derived from the $\mathrm{H} 1 \mathrm{~N} 1$ virus $\mathrm{A} / \mathrm{PR} / 8 / 34$, which was isolated in Puerto Rico in 1934 and is commonly used in animal studies (Lipatov et al. 2005b; Subbarao et al. 2003). The HA gene was further modified to replace the stretch of six basic amino acids at the cleavage site that can be digested by furin (Shi et al. 2007), and the resulting virus is avirulent in chickens and can be grown readily in eggs.

Most vaccines for highly pathogenic H5N1 tested to date were based on inactivated or attenuated virus used with or without adjuvant (Matsuoka et al. 2003; Subbarao et al. 2003; Lipatov et al. 2005b; Stephenson et al. 2005). These vaccines achieved protection in mice, ferrets, or birds against pathogenic subtypes of influenza A virus expressing the same or a closely related HA through the induction of neutralizing antibodies. In a human clinical trial with an inactivated $\mathrm{H} 5 \mathrm{~N} 1$ influenza virus vaccine attenuated through reverse genetics and changes of the HA cleavage site to allow propagation in eggs, protective titers of neutralizing Abs could be induced in volunteers after two doses of the vaccine (Treanor et al. 2006). Unfortunately, the dose that was needed to induce immune responses was six times that used for current influenza A virus vaccines. In a subsequent larger trial, the vaccine was adjuvanted with aluminum hydroxide, which did not improve the vaccine's immunogenicity (Bresson et al. 2006). Others reported the opposite results (Leroux-Roels et al. 2007). Additional clinical trials were conducted with inactivated whole-virus vaccine, which caused seroconversion in $~ 80 \%$ of vaccines that received the highest vaccine dose $(10 \mathrm{mg})$, again indicating that the HA of H5N1 viruses is not a potent inducer of neutralizing antibody responses (Lin et al. 2006). The immunogenicity of H5N1 vaccine could be increased by adding MF59 adjuvant (Nicholson et al. 2001). Clinical trials have also been initiated with an attenuated $\mathrm{H} 5 \mathrm{~N} 1$ vaccine. ${ }^{5}$

\footnotetext{
${ }^{5}$ See http://www.nih.gov/news/pr/sep2006/niaid.//.htm
} 
A number of groups have developed subunit vaccines for H5N1 virus. A DNA vaccine encoding $\mathrm{H} 5$ provided partial protection against challenge with $\mathrm{H} 5 \mathrm{~N} 1$ virus (Bright et al. 2003), while DNA vaccines encoding NP or M were comparatively ineffective (Epstein et al. 2002). DNA vaccine priming followed by a booster immunization with a replication-defective vector of adenovirus of the human serotype 5 (AdHu5), both expressing NP, augmented specific $\mathrm{T}$ cell responses and provided superior protection against challenge (Epstein et al. 2005). Two groups explored AdHu5 vectors expressing H5; they were shown to induce B and T cell responses against $\mathrm{HA}$ which protected against challenge with a pathogenic $\mathrm{H} 5 \mathrm{~N} 1$ virus (Gao et al. 2006; Hoelscher et al. 2006). Nevertheless, it should be pointed out that seroprevalence rates of neutralizing antibodies to AdHu5 are high in humans, especially those living in Asia or Africa, and that such antibodies strongly dampen antibody responses to the transgene product expressed by an AdHu5 vector. Fowl pox vectors (Qiao et al. 2006) and alpha virus replicons (Schultz-Cherry et al. 2000) expressing H5 were also shown to induce protective immunity against H5N1 influenza viruses.

In 2003, a H7N7 virus caused an outbreak in poultry in the Netherlands during which 88 humans became infected and mainly developed conjunctivitis, while one died of complications due to pneumonia. The virus isolated from the fatal case showed a mutation in the polymerase gene that was similar to that of highly pathogenic H5N1 (Munster et al. 2007). A reassortant vaccine expressing H7 and N7 on the A/PR8 background was developed, and an inactivated adjuvanted form of this vaccine induced neutralizing antibodies and protection in mice after two doses (de Wit et al. 2005).

A low-pathogenic subtype of H7N2 has been circulating in poultry in the northeastern USA since 1994, while highly pathogenic avian influenza has sporadically appeared, such as in an outbreak in Chile (H7N3) in 2002, an outbreak in the United States (H5N2) in 2004, and an outbreak in Canada (H7N3) in 2004 (Senne 2007). These viruses readily become pathogenic through some mutations (Lee et al. 2006) and thus pose a pandemic threat. A reassortant vaccine has been generated against $\mathrm{H} 7 \mathrm{~N} 2$ and was shown to induce protective immunity in mice and ferrets (Pappas et al. 2007).

Thus far, only one H5N1 influenza vaccine has been licensed by the United States Food and Drug Administration (FDA), while a number of other candidate vaccines against $\mathrm{H} 5 \mathrm{~N} 1$ avian influenza are in clinical trials and should be licensed in the near future. Whether or not these vaccines will be protective against the next pandemic virus is unknown. Initiating widespread vaccination before the actual pandemic starts would thus raise ethical questions - any vaccine, even one that is well tolerated, carries risks for the recipients. Without any clear indication that $\mathrm{H} 5 \mathrm{~N} 1$ is turning into a pandemic virus, the risk of vaccination would surpass the benefit to the vaccinated individual. This was demonstrated during the swine flu vaccine debacle of 1976, when vaccination against a virus that never spread caused a serious, crippling disease in hundreds of recipients. In addition to causing harm to these unfortunate individuals, this incident continues to provide ammunition to the vocal community of vaccine opponents that seem to have forgotten the haunting 
images of humans disfigured by poxviruses or wards full of polio virus-infected children on iron lungs. In contrast, a universal vaccine could be given before a pandemic, as such a vaccine would prevent seasonal influenza, thus providing a tangible benefit to its recipients.

\subsection{Pragmatic Attitude}

Scio me nihil scire (I know that I don't know) is a famous saying attributed to the Greek philosopher Socrates by Plato. If we take a Socratic view of the form and shape of the next pandemic influenza virus, mass production of a vaccine that induces protection through subtype-specific antibodies before a pandemic virus has actually evolved makes no sense. Making sure that an infrastructure is in place to rapidly and efficiently respond to a pandemic is, on the other hand, a prudent approach, and global agencies such as WHO in concert with governments are preparing for the next pandemic. Constant monitoring of evolving subtypes, new human infections and potential human-to-human spread in order to detect a pandemic at the earliest possible time is a vital task, and this been established. The sharing of virus isolates to identify potential vaccine candidates is important and requires international collaboration. Indonesia, which has the highest incidence of H5N1related human deaths, initially refused to provide $\mathrm{H} 5 \mathrm{~N} 1$ samples to $\mathrm{WHO}$ in order to focus attention on their concern that while developing countries provide new viral isolates, any resulting vaccines produced by commercial companies would likely be used primarily in developed countries. By March 2007, Indonesia, which was the only country that took this stance, reversed its policy.

To date, global vaccine production capacity is insufficient, as seasonal influenza vaccines are only used by a small portion of the global population. A number of vaccine manufacturers have started to increase their production capacity, and it is expected that the current capacity will double by 2009. The long-term goal is to increase production capacity to three billion doses per year. It is also expected that manufacturing will commence in less developed countries. Idiosyncrasies of the actual pandemic vaccine, such as the required dose and the potential need for repeat injections, will determine whether this capacity will suffice. This is being addressed by attempts to increase the immunogenicity of influenza virus vaccines through novel adjuvants. Poorly growing vaccine subtypes could also offset the speed of production, and this is being tackled by developing cell-culture-based systems and through the use of reverse genetics to achieve rapid attenuation of influenza viruses. Recent studies indicated that antibodies to currently circulating viruses show some cross-reactivity with H5N1. ${ }^{6}$ These studies must be confirmed. If indeed annual vaccinations with certain types of vaccine offer some degree of heterotypic protection

\footnotetext{
${ }^{6}$ Sandbulte MR, et al. 2007 Cross-reactive neuraminidase antibodies afford partial protection against $\mathrm{H} 5 \mathrm{~N} 1$ in mice and are presection unexposed humans PLoS Med
} 
a broadening of seasonal influenza vaccine coverage would certainly be warranted, especially in countries that have advanced to a "pandemic alert period."

Progression through all of the steps of vaccine development, from preclinical trials in rodents through to clinical trials in humans and then licensing, generally takes 5-10 years. The FDA, which regulates vaccine licensure in the USA, has formulated guidelines for industry for the accelerated licensure of pandemic influenza vaccines based on the induction of neutralizing antibodies to hemagglutinin in order to ensure that regulatory aspects do not hinder the rapid deployment of a pandemic vaccine. Vaccines that do not contain viral hemagglutinin are not covered by these guidelines.

Nevertheless, even if the production of a vaccine starts on the day that a pandemic virus has been identified, it will still take 4-6 months until the very first dose of vaccine is available. Other control measures are therefore needed to limit damage until the vaccines become available for everyone. In the USA, the federal government and state governments have formulated pandemic preparedness plans to be followed in the event of a pandemic. These plans not only list the responsibilities of government entities and individuals, but also address the use of limited pharmacological agents and other types of control measures. Similar to vaccines, the availability of antiviral drugs is expected to be limited. Antiviral drugs may slow the pandemic if used in a timely manner at the epicenter of the pandemic. They may also be extraordinarily useful for protecting persons that provide essential healthcare and for maintaining vital infrastructure.

Assuming a delay of at least 6-12 months before sufficient doses of vaccine are available for global mass vaccination, vaccines will have to be rationed at the beginning of the pandemic. Governments will issue lists of high-priority personnel that are to be vaccinated first. Although these lists vary from state to state in the USA, they typically include hospital and health department staff, emergency medical service personnel and household members, law enforcement personnel, fire fighters, medical laboratory workers, emergency management personnel, long-term care facility staff, utility workers (gas, electric, water, waste management, etc.), communications personnel, fuel and food suppliers, public transportation and air travel personnel, corrections workers, morticians/coroners/medical examiners, pharmacists, Red Cross field workers, US postal service staff, persons involved with vaccine production and delivery, etc. It has been suggested that once more vaccine becomes available, healthy working adults should be vaccinated before high-risk populations such as children or the elderly.

It is still to be decided who will ultimately purchase the pandemic vaccinefederal or state governments, who could clearly facilitate orderly distribution, or the private sector. If the private sector carries the cost, insurance companies will have to take a stance on cost coverage, and plans will have to be developed for the uninsured.

Once a vaccine becomes available, other problems will arise. Some of these issues are being addressed by governments, and the examples below apply to the USA. A pandemic vaccine would not be expected to undergo the vigorous safety testing typical of other vaccines. Manufacturers that develop pandemic vaccines 
can request indemnification from the Secretary of Health and Human Services for "an activity that involves unusually hazardous risks and for which insurance is not available or sufficient to cover those risks."

A vaccine will have to be distributed rapidly and in an orderly manner. The US government ruled that it may mobilize the PHS Commissioned Corps to distribute vaccines to federal agencies with direct patient care responsibilities, or to states, tribes, and other localities through the National Disaster Medical System and through agreements between the federal government, states, and localities.

Liability protection must be put in place. The US government has ruled that federal employee administrators are covered by the federal government and could make claims through the Federal Tort Claims Act. State employees may be covered for malpractice or tort claims coverage under state law. Federal contractor and private sector employees distributing the vaccine would be expected to carry malpractice insurance or they could be covered by the Volunteer Protection Act, State Good Samaritan Act, or State Emergency Compact provisions. If a person is injured following administration of a pandemic vaccine or antiviral medication in connection with his/her employment, compensation may be available under a state's worker's compensation program. For federal employees, compensation may be available under the Federal Employees' Compensation Act.

Assuming that vaccines will not be available at the onset of the next pandemic, other nonpharmaceutical measures are being discussed to (1) limit international spread, (2) reduce spread within national and local populations, and (3) reduce an individual person's risk for infection.

Influenza viruses are typically shed $24-48 \mathrm{~h}$ before the onset of disease, and virus titers peak within the first three days after onset of symptoms and then decline by day 7-8. It is possible but not yet proven that the virus spreads by shedding a small amount of virions before the first symptoms occur, which could markedly reduce the effectiveness of most quarantine measures. Infection occurs predominantly via droplets formed by coughing or sneezing individuals. Infection by aerosolized virus is less common. The virus can also be transmitted via infected hands or surfaces. The wearing of masks and the employment of appropriate sanitizing measures to clean hands and infected surfaces are thus useful actions for protecting an individual (Jefferson et al. 2008).

It is thought that temporary protection of populations may in part be achieved by implementing quarantine measures. In the pandemic of 1918, some island countries enacted maritime quarantines (Markel et al. 2007). Australia and Madagascar were able to delay the start of the pandemic by several months, while Samoa and New Caledonia remained completely free of the pandemic. Quarantine measures were attempted on land, but they were unsuccessful. Quarantine was tried again in 1957, but it largely failed. Quarantine was very successful in stopping the SARS epidemic of 2003 (Hsieh et al. 2007). The SARS virus has a longer incubation time than influenza virus, and peak virus titers are not reached until several days after the onset of symptoms. Isolating cases thus proved an effective way to prevent the further spread of SARS, but it is unlikely to work against influenza virus. WHO recommends exit screening for international travelers that leave countries that are affected 
by an influenza virus pandemic. It is unclear if and to what extent this may delay the spread of the virus. However, any delay would be useful in allowing extra time for vaccine production.

The US government has issued an Executive Order adding potentially pandemic influenza viruses to the list of quarantinable diseases, which empowers the Centers for Disease Control and Prevention (CDC) to detain, medically examine, or conditionally release individuals that are reasonably believed to be carrying a communicable disease. The intent of this order is to enable the United States to respond efficiently and effectively in the case of an outbreak by pandemic influenza viruses. This order gives legal authority to the Department of Health and Human Services to isolate a passenger arriving on board an international vessel that show evidence of infection with a novel influenza virus, even if that passenger refuses to cooperate. The federal government (such as the CDC) generally defers to the state and local health authorities in the use of their own quarantine powers. State-implemented interventions would likely include the isolation and treatment of infected individuals, voluntary home quarantine for members of the households of infected individuals, the closure of schools and universities, and the encouragement of social distancing through the cancellation of large public gatherings.

\subsection{Worst Case Scenario}

WHO estimates that in the worst case scenario more than 70 million people could die as a consequence of the next influenza virus pandemic. Other estimates are higher: 180-360 million deaths. To put this number into perspective, 360 million is approximately the total population of South America, or half of the population of Europe. Death tolls will primarily depend on the virulence of the next pandemic - current clades of highly pathogenic H5N1 virus kill $>60 \%$ of those infected. It would also depend on the ease with which the virus is transmitted between humans, and last but not least on the effectiveness of control measures. Late detection of a pandemic, which could evolve in a war-ravaged country that lacks surveillance, would shorten the time interval available for the development of a vaccine. Vaccine production could be further delayed by problems with the seed virus, such as toxicity toward eggs or cell substrates, poor immunogenicity of the vaccine, or unacceptable reactogenicity. The modern world, with its high degree of social and economic interdependency, has not yet experienced a major pandemic that disrupts crucial aspects of local and global infrastructure. Lack of available workers and restricted movement could threaten essential services, and the failure of any one system could trigger others to fail too, causing cascading breakdowns.

Highly pathogenic H5N1 influenza viruses have been circulating for more than ten years and many have come to believe that they are unlikely to jump species. Although this may well be the case, the consequences of relaxing our efforts to prepare for the next pandemic could be horrific. 


\section{Summary}

In 1969, when smallpox virus was on the brink of extinction and polio was disappearing from developed countries, the US Surgeon General, William Stewart, told Congress that it was time to "close the books on infectious diseases." Unfortunately, Congress listened and shifted federal funding from microbiology/virology to cancer and cardiovascular diseases. Ever-increasing liability costs made the industry more and more reluctant to stay involved in vaccine production, and the number of companies that produce vaccines has now become so limited that annual vaccine shortages are common (Markel et al. 2007). Infectious agents have continued to take a major toll on human lives. Since 1969 more than 30 new microbes have emerged, such as HIV-1, which has claimed over 22 million lives thus far. Even old microbes such as influenza virus continue to take a toll on human lives; for example, in the USA alone, seasonal influenza causes over 200,000 hospitalizations and over 30,000 death each year. The world will experience a new influenza virus pandemic. No-one can predict when it will happen, where it will start, what virus will cause it, and what the global and local impacts will be. The only aspect of the next pandemic we can predict with certainty is that it will happen.

Complacency, not only in the USA but worldwide, has weakened the infrastructure for efficiently combating newly emerging infectious agents, and this infrastructure needs to be rebuilt. Communications with the public must be improved globally in a manner that informs accurately without alarming unduly. It is clear that this has not yet been achieved, as exemplified by a recent H5N1 outbreak in West Bengal in India, ${ }^{7}$ where children were reported to have unprotected contact with birds that died due to infection with H5N1.

Our continued lack of knowledge about the very basic question of the immunobiology of influenza viruses and the efficacy of vaccines in different cohorts is mind-boggling. We still do not fully understand correlates of protection against influenza virus, and debates on the role of $\mathrm{CD}^{+} \mathrm{T}$ cells in providing protection are continuing. This knowledge needs to be generated, especially in order to enable the development of a universal influenza virus vaccine, the "holy grail" that could prevent future influenza virus pandemics.

\section{References}

Abe T, Takahashi H, Hamazaki H, Miyano-Kurosaki N, Matsuura Y, Takaku H (2003) Baculovirus induces an innate immune response and confers protection from lethal influenza virus infection in mice. J Immunol 171:1133-1139

Altstein AD, Gitelman AK, Smirnov YA, Piskareva LM, Zakharova LG, Pashvykina GV, Shmarov MM, Zhirnov OP, Varich NP, Ilyinskii PO, Shneider AM (2006) Immunization with influenza

\footnotetext{
${ }^{7}$ www.recombinomics.com/News/01160801/H5N1.Birbhun_Suspect.z.htm
} 
A NP-expressing vaccinia virus recombinant protects mice against experimental infection with human and avian influenza viruses. Arch Virol 151:921-931

Amonsin A, Songserm T, Chutinimitkul S, Jam-On R, Sae-Heng N, Pariyothorn N, Payungporn S, Theamboonlers A, Poovorawan Y (2007) Genetic analysis of influenza A virus (H5N1) derived from domestic cat and dog in Thailand. Arch Virol 152:1925-1933

Andrew ME, Coupar BE, Ada GL, Boyle DB (1986) Cell-mediated immune responses to influenza virus antigens expressed by vaccinia virus recombinants. Microb Pathog 1:443-452

Aydar Y, Balogh P, Tew JG, Szakal AK (2004) Follicular dendritic cells in aging, a "bottle-neck" in the humoral immune response. Ageing Res Rev 3:15-29

Beilharz MW, Cummins JM, Bennett AL (2007) Protection from lethal influenza virus challenge by oral type 1 interferon. Biochem Biophys Res Commun 355:740-744

Biro J (1978) Age-related change of the absolute number of IgG-, and IgM-bearing B-lymphocytes and T-lymphocytes in human peripheral blood following influenza vaccination. Aktuelle Gerontol 8:81-83

Bresson JL, Perronne C, Launay O, Gerdil C, Saville M, Wood J et al (2006) Safety and immunogenicity of an inactivated split-virion influenza A/Vietnam/1194/2004 (H5N1) vaccine: phase 1 randomised trial. Lancet 367:1657-1664

Bright RA, Ross TM, Subbarao K, Robinson HL, Katz JM (2003) Impact of glycosylation on the immunogenicity of a DNA-based influenza H5 HA vaccine. Virology 308:270-278

Callan RJ, Hartmann FA, West SE, Hinshaw VS (1997) Cleavage of influenza A virus H1 hemagglutinin by swine respiratory bacterial proteases. J Virol 71:7579-7585

Cella M, Facchetti F, Lanzavecchia A, Colonna M (2000) Plasmacytoid dendritic cells activated by influenza virus and CD40L drive a potent TH1 polarization. Nat Immunol 1:305-310

Centers for Disease Control and Prevention (1997) Isolation of avian influenza A(H5N1) viruses from humans-Hong Kong, May-December 1997. MMWR Morb Mortal Wkly Rep 46:1204-1207

Cerwenka A, Morgan TM, Dutton RW (1999) Naive, effector, and memory CD8 T cells in protection against pulmonary influenza virus infection: homing properties rather than initial frequencies are crucial. J Immunol 163:5535-5543

Cheung CL, Rayner JM, Smith GJ, Wang P, Naipospos TS, Zhang J, Yuen KY, Webster RG, Peiris JS, Guan Y, Chen H (2006) Distribution of amantadine-resistant H5N1 avian influenza variants in Asia. J Infect Dis 193:1626-1629

Cockburn WC, Delon PJ, Ferreira W (1969) Origin and progress of the 1968-69 Hong Kong influenza epidemic. Bull World Health Organ 41:345-348

Cristalli A, Capua I (2007) Practical problems in controlling H5N1 high pathogenicity avian influenza at village level in Vietnam and introduction of biosecurity measures. Avian Dis 51:461-462

De Filette M, Ramne A, Birkett A, Lycke N, Lowenadler B, Min Jou W, Saelens X, Fiers W (2006) The universal influenza vaccine M2e-HBc administered intranasally in combination with the adjuvant CTA1-DD provides complete protection. Vaccine 24:544-551

de Wit E, Munster VJ, Spronken MI, Bestebroer TM, Baas C, Beyer WE, Rimmelzwaan GF, Osterhaus AD, Fouchier RA (2005) Protection of mice against lethal infection with highly pathogenic H7N7 influenza A virus by using a recombinant low-pathogenicity vaccine strain. J Virol 79:12401-12407

Demicheli V, Rivetti D, Deeks J, Jefferson T (2004) Vaccines for preventing influenza in healthy adults. Cochrane Database Syst Rev CD001269

Dunn FL (1958) Pandemic influenza in 1957; review of international spread of new Asian strain. J Am Med Assoc 166:1140-1148

Dull HB, Jensen J, Rakich JH, Cohen A, Henderson DA, Pirkle CI (1960) Monovalent Asian influenza vaccine: evaluation of its use during two waves of epidemic Asian influenza in partly immunized penitentiary population. JAMA 172:1223-1229

Effros RB, Cai Z, Linton PJ (2003) CD8 T cells and aging. Crit Rev Immunol 23:45-64

Endo A, Itamura S, Iinuma H, Funahashi S, Shida H, Koide F, Nerome K, Oya A (1991) Homotypic and heterotypic protection against influenza virus infection in mice by recombinant vaccinia virus expressing the haemagglutinin or nucleoprotein of influenza virus. J Gen Virol 72:699-703 
Epstein SL (2006) Prior H1N1 influenza infection and susceptibility of Cleveland Family Study participants during the H2N2 pandemic of 1957: an experiment of nature. J Infect Dis 193:49-53

Epstein SL, Tumpey TM, Misplon JA, Lo CY, Cooper LA, Subbarao K, Renshaw M, Sambhara S, Katz JM (2002) DNA vaccine expressing conserved influenza virus proteins protective against H5N1 challenge infection in mice. Emerg Infect Dis 8:796-801

Epstein SL, Kong WP, Misplon JA, Lo CY, Tumpey TM, Xu L, Nabel GJ (2005) Protection against multiple influenza A subtypes by vaccination with highly conserved nucleoprotein. Vaccine 23:5404-5410

Ernst WA, Kim HJ, Tumpey TM, Jansen AD, Tai W, Cramer DV et al. (2006) Protection against $\mathrm{H} 1, \mathrm{H} 5, \mathrm{H} 6$ and $\mathrm{H} 9$ influenza A infection with liposomal matrix 2 epitope vaccines. Vaccine 24:5158-5168

EurekAlert (2007) Universal flu vaccine being tested on humans. http://www.eurekalert.org/ pub_releases/2007-07/vfii-nuf071707.php

Falk K, Rötzschke O, Deres K, Metzger J, Jung G, Rammensee HG (1991) Identification of naturally processed viral nonapeptides allows their quantification in infected cells and suggests an allele-specific T cell epitope forecast. J Exp Med 174:425-434

Fan J, Liang X, Horton MS, Perry HC, Citron MP, Heidecker GJ, Fu TM, Joyce J, Przysiecki CT, Keller PM, Garsky VM, Ionescu R, Rippeon Y, Shi L, Chastain MA, Condra JH, Davies ME, Liao J, Emini EA, Shiver JW (2004) Preclinical study of influenza virus A M2 peptide conjugate vaccines in mice, ferrets, and rhesus monkeys. Vaccine 22:2993-3003

Fattal-German M, Bizzini B (1992) Assessment of the anti-viral effect of a short-term oral treatment of mice with live Saccharomyces cerevisiae cells. Dev Biol Stand 77:115-120

Feng J, Zhang M, Mozdzanowska K, Zharikova D, Hoff H, Wunner W, Couch RB, Gerhard W (2006) Influenza A virus infection engenders a poor antibody response against the ectodomain of matrix protein 2. Virol $\mathrm{J}$ 3:102

Frace AM, Klimov AI, Rowe T, Black RA, Katz JM (1999) Modified M2 proteins produce heterotypic immunity against influenza A virus. Vaccine 17:2237-2244

Francis T, Salk JE, Pearson HE, Brown PN (1945a) Protective effect of vaccination against induced influenza A. J Clin Invest 24:536-546

Francis T, Salk JE, Pearson HE, Brown PN (1945b) Protective effect of vaccination against induced influenza B. J Clin Invest 24:547-553

Fu TM, Friedman A, Ulmer JB, Liu MA, Donnelly JJ (1997) Protective cellular immunity: cytotoxic T-lymphocyte responses against dominant and recessive epitopes of influenza virus nucleoprotein induced by DNA immunization. J Virol 71:2715-2721

Gao W, Soloff AC, Lu X, Montecalvo A, Nguyen DC, Matsuoka Y, Robbins PD, Swayne DE, Donis RO, Katz JM, Barratt-Boyes SM, Gambotto A (2006) Protection of mice and poultry from lethal H5N1 avian influenza virus through adenovirus-based immunization. J Virol 80:1959-1964

Gentile D, Doyle W, Whiteside T, Fireman P, Hayden FG, Skoner D (1998) Increased interleukin-6 levels in nasal lavage samples following experimental influenza A virus infection. Clin Diagn Lab Immunol 5:604-608

Geraci JR, St Aubin DJ, Barker IK, Webster RG, Hinshaw VS, Bean WJ, Ruhnke HL, Prescott JH, Early G, Baker AS, Madoff S, Schooley RT (1982) Mass mortality of harbor seals: pneumonia associated with influenza A virus. Science 215:1129-1131

Ginaldi L, De Martinis M, D’Ostilio A, Marini L, Loreto MF, Corsi MP, Quaglino D (1999a) The immune system in the elderly: I. Specific humoral immunity. Immunol Res 20:101-108

Ginaldi L, De Martinis M, D’Ostilio A, Marini L, Loreto MF, Martorelli V, Quaglino D (1999b) The immune system in the elderly: II. Specific cellular immunity. Immunol Res 20:109-115

Ginaldi L, De Martinis M, D’Ostilio A, Marini L, Loreto MF, Quaglino D (1999c) The immune system in the elderly: III. Innate immunity. Immunol Res 20:117-126

Gramer MR, Lee JH, Choi YK, Goyal SM, Joo HS (2007) Serologic and genetic characterization of North American H3N2 swine influenza A viruses. Can J Vet Res 71:201-206

Gundlefinger BF, Stille WT, Bell JA (1958) Effectiveness of influenza vaccines during an epidemic of Asian influenza. New Engl J Med 259:1005-1009 
Halperin SA, Smith B, Mabrouk T, Germain M, Trepanier P, Hassell T et al. (2002) Safety and immunogenicity of a trivalent, inactivated, mammalian cell culture-derived influenza vaccine in healthy adults, seniors, and children. Vaccine 20:1240-1247

Hanson BJ, Boon AC, Lim AP, Webb A, Ooi EE, Webby RJ (2006) Passive immunoprophylaxis and therapy with humanized monoclonal antibody specific for influenza A H5 hemagglutinin in mice. Respir Res 7:126

Heinen PP, Rijsewijk FA, de Boer-Luijtze EA, Bianchi AT (2002) Vaccination of pigs with a DNA construct expressing an influenza virus M2-nucleoprotein fusion protein exacerbates disease after challenge with influenza A virus. J Gen Virol 83:1851-1859

Hoelscher MA, Garg S, Bangari DS, Belser JA, Lu X, Stephenson I, Bright RA, Katz JM, Mittal SK, Sambhara S (2006) Development of adenoviral-vector-based pandemic influenza vaccine against antigenically distinct human H5N1 strains in mice. Lancet 367:475-481

Hsieh YH, King CC, Chen CW, Ho MS, Hsu SB, Wu YC (2007) Impact of quarantine on the 2003 SARS outbreak: a retrospective modeling study. J Theor Biol 244:729-736

Huleatt JW, Nakaar V, Desai P, Huang Y, Hewitt D, Jacobs A, Tang J, McDonald W, Song L, Evans RK, Umlauf S, Tussey L, Powell TJ (2008) Potent immunogenicity and efficacy of a universal influenza vaccine candidate comprising a recombinant fusion protein linking influenza M2e to the TLR5 ligand flagellin. Vaccine 26:201-214

Hulse DJ, Webster RG, Russell RJ, Perez DR (2004) Molecular determinants within the surface proteins involved in the pathogenicity of H5N1 influenza viruses in chickens. J Virol 78:9954-9964

Irinoda K, Masihi KN, Chihara G, Kaneko Y, Katori T (1992) Stimulation of microbicidal host defence mechanisms against aerosol influenza virus infection by lentinan. Int J Immunopharmacol 14:971-977

Ison MG, Hayden FG (2001) Therapeutic options for the management of influenza. Curr Opin Pharmacol 1:482-490

Janssens JP, Krause KH (2004) Pneumonia in the very old. Lancet Infect Dis 4:112-124

Jao RL, Wheelock EF, Jackson GG (1970) Production of interferon in volunteers infected with Asian influenza. J Infect Dis 121:419-426

Jayasekera JP, Moseman EA, Carroll MC (2007) Natural antibody and complement mediate neutralization of influenza virus in the absence of prior immunity. J Virol 81:3487-3494

Jefferson T, Rivetti D, Rivetti A, Rudin M, Di Pietrantonj C, Demicheli V (2005) Efficacy and effectiveness of influenza vaccines in elderly people: a systematic review. Lancet 366:1165-1174

Jefferson T, Foxlee R, Del Mar C, Dooley L, Ferroni E, Hewak B, Prabhala A, Nair S, Rivetti A (2008) Physical interventions to interrupt or reduce the spread of respiratory viruses: systematic review. BMJ 336:77-80

Johnson NP, Mueller J (2002) Updating the accounts: global mortality of the 1918-1920 "Spanish" influenza pandemic. Bull Hist Med 76:105-115

Jordan RE, Hawker JI, Ayres JG, Tunnicliffe W, Adab P, Olowokure B, Kai J, McManus RJ, Salter R, Cheng KK (2006) Influenza-related mortality in the Italian elderly: no decline associated with increasing vaccination coverage. Vaccine 24:6468-6475

Kash JC, Basler CF, García-Sastre A, Carter V, Billharz R, Swayne DE, Przygodzki RM, Taubenberger JK, Katze MG, Tumpey TM (2004) Global host immune response: pathogenesis and transcriptional profiling of type A influenza viruses expressing the hemagglutinin and neuraminidase genes from the 1918 pandemic virus. J Virol 78:9499-9511

Kaye HS, Dowdle WR, McQueen JL (1969) Studies on inactivated influenza vaccines. I. The effect of dosage on antibody response and protection against homotypic and heterotypic influenza virus challenge in mice. Am J Epidemiol 90:162-169

Keawcharoen J, Oraveerakul K, Kuiken T, Fouchier RA, Amonsin A, Payungporn S, Noppornpanth S, Wattanodorn S, Theambooniers A, Tantilertcharoen R, Pattanarangsan R, Arya N, Ratanakorn P, Osterhaus DM, Poovorawan Y (2004) Avian influenza H5N1 in tigers and leopards. Emerg Infect Dis 10:2189-2191

Kilbourne ED (2006) Influenza pandemics of the 20th century. Emerg Infect Dis 12:9-14

Koopmans M, Wilbrink B, Conyn M, Natrop G, van der Nat H, Vennema H, Meijer A, van Steenbergen J, Fouchier R, Osterhaus A, Bosman A (2004) Transmission of H7N7 avian 
influenza A virus to human beings during a large outbreak in commercial poultry farms in the Netherlands. Lancet 363:587-593

Langmuir AD, Bregman DJ, Kurland LT, Nathanson N, Victor M (1984) An epidemiologic and clinical evaluation of Guillain-Barré syndrome reported in association with the administration of swine influenza vaccines. Am J Epidemiol 119:841-879

Lawson CM, Bennink JR, Restifo NP, Yewdell JW, Murphy BR (1994) Primary pulmonary cytotoxic T lymphocytes induced by immunization with a vaccinia virus recombinant expressing influenza A virus nucleoprotein peptide do not protect mice against challenge. J Virol 68:3505-3511

Lee CW, Lee YJ, Senne DA, Suarez DL (2006) Pathogenic potential of North American H7N2 avian influenza virus: a mutagenesis study using reverse genetics. Virology 353:388-395

Leroux-Roels I, Borkowski A, Vanwolleghem T, Dramé M, Clement F, Hons E, Devaster JM, Leroux-Roels G (2007) Antigen sparing and cross-reactive immunity with an adjuvanted rH5N1 prototype pandemic influenza vaccine: a randomised controlled trial. Lancet 370:580-589

Lessler J, Cummings DA, Fishman S, Vora A, Burke DS (2007) Transmissibility of swine flu at Fort Dix, 1976. J R Soc Interface 4:755-762

Lin J, Zhang J, Dong X, Fang H, Chen J, Su N, Gao Q, Zhang Z, Liu Y, Wang Z, Yang M, Sun R, Li C, Lin S, Ji M, Liu Y, Wang X, Wood J, Feng Z, Wang Y, Yin W (2006) Safety and immunogenicity of an inactivated adjuvanted whole-virion influenza A (H5N1) vaccine: a phase I randomised controlled trial. Lancet 368:991-997

Lipatov AS, Andreansky S, Webby RJ, Hulse DJ, Rehg JE, Krauss S, Perez DR, Doherty PC, Webster RG, Sangster MY (2005a) Pathogenesis of Hong Kong H5N1 influenza virus NS gene reassortants in mice: the role of cytokines and B and T cell responses. J Gen Virol 86:1121-1130

Lipatov AS, Webby RJ, Govorkova EA, Krauss S, Webster RG (2005b) Efficacy of H5 influenza vaccines produced by reverse genetics in a lethal mouse model. J Infect Dis 191:1216-1220

Liu W, Zou P, Chen YH (2004) Monoclonal antibodies recognizing EVETPIRN epitope of influenza A virus M2 protein could protect mice from lethal influenza A virus challenge. Immunol Lett 93:131-136

Liu W, Zou P, Ding J, Lu Y, Chen YH (2005) Sequence comparison between the extracellular domain of M2 protein human and avian influenza A virus provides new information for bivalent influenza vaccine design. Microbes Infect 7:171-177

López CB, Moltedo B, Alexopoulou L, Bonifaz L, Flavell RA, Moran TM (2004) TLRindependent induction of dendritic cell maturation and adaptive immunity by negative-strand RNA viruses. J Immunol 173:6882-6889

Mak NK, Leung KN, Ada GL (1982) The generation of 'cytotoxic' macrophages in mice during infection with influenza A or Sendai virus. Scand J Immunol 15:553-561

Malaguarnera L, Ferlito L, Imbesi RM, Gulizia GS, Di Mauro S, Maugeri D, Malaguarnera M, Messina A (2001) Immunosenescence: a review. Arch Gerontol Geriatr 32:1-14

Manzoli L, Schioppa F, Boccia A, Villari P (2007) The efficacy of influenza vaccine for healthy children: a meta-analysis evaluating potential sources of variation in efficacy estimates including study quality. Pediatr Infect Dis J 26:97-106

Markel H, Lipman HB, Navarro JA, Sloan A, Michalsen JR, Stern AM, Cetron MS (2007) Nonpharmaceutical interventions implemented by US cities during the 1918-1919 influenza pandemic. JAMA 298:644-654

Matsuoka Y, Chen H, Cox N, Subbarao K, Beck J, Swayne D (2003) Safety evaluation in chickens of candidate human vaccines against potential pandemic strains of influenza. Avian Dis 47:926-930

Mbawuike IN, Zhang Y, Couch RB (2007) Control of mucosal virus infection by influenza nucleoprotein-specific CD8+ cytotoxic T lymphocytes. Respir Res 8:44

McCullers JA (2006) Insights into the interaction between influenza virus and pneumococcus. Clin Microbiol Rev 19:571-582

McLain L, Dimmock NJ (1989) Protection of mice from lethal influenza by adoptive transfer of non-neutralizing haemagglutination-inhibiting $\operatorname{IgG}$ obtained from the lungs of infected animals treated with defective interfering virus. J Gen Virol 70:2615-2624 
Mozdzanowska K, Feng J, Eid M, Kragol G, Cudic M, Otvos L Jr, Gerhard W (2003) Induction of influenza type A virus-specific resistance by immunization of mice with a synthetic multiple antigenic peptide vaccine that contains ectodomains of matrix protein 2. Vaccine 21:2616-2626

Mozdzanowska K, Furchner M, Zharikova D, Feng J, Gerhard W (2005) Roles of CD4+ T cellindependent and -dependent antibody responses in the control of influenza virus infection: evidence for noncognate CD4+ T cell activities that enhance the therapeutic activity of antiviral antibodies. J Virol 79:5943-5951

Munster VJ, de Wit E, van Riel D, Beyer WE, Rimmelzwaan GF, Osterhaus AD, Kuiken T, Fouchier RA (2007) The molecular basis of the pathogenicity of the Dutch highly pathogenic human influenza A H7N7 viruses. J Infect Dis 196:258-265

Murasko DM, Bernstein ED, Gardner EM, Gross P, Munk G, Dran S, Abrutyn E (2002) Role of humoral and cell-mediated immunity in protection from influenza disease after immunization of healthy elderly. Exp Gerontol 37:427-439

Neirynck S, Deroo T, Saelens X, Vanlandschoot P, Jou WM, Fiers W (1999) A universal influenza A vaccine based on the extracellular domain of the M2 protein. Nat Med 5:1157-1163

Nichol KL, Nordin JD, Nelson DB, Mullooly JP, Hak E (2007) Effectiveness of influenza vaccine in the community-dwelling elderly. N Engl J Med 357:1373-1381

Nicholson KG, Colegate AE, Podda A, Stephenson I, Wood J, Ypma E, Zambon MC (2001) Safety and antigenicity of non-adjuvanted and MF59-adjuvanted influenza A/Duck/ Singapore/97 (H5N3) vaccine: a randomised trial of two potential vaccines against H5N1 influenza. Lancet 357:1937-1943

Okuno Y, Matsumoto K, Isegawa Y, Ueda S (1994) Protection against the mouse-adapted A/ FM/1/47 strain of influenza A virus in mice by a monoclonal antibody with cross-neutralizing activity among $\mathrm{H} 1$ and $\mathrm{H} 2$ strains. J Virol 68:517-520

Oxburgh L, Hagström A (1999) A PCR based method for the identification of equine influenza virus from clinical samples. Vet Microbiol 67:161-174

Pappas C, Matsuoka Y, Swayne DE, Donis RO (2007) Development and evaluation of an Influenza virus subtype $\mathrm{H} 7 \mathrm{~N} 2$ vaccine candidate for pandemic preparedness. Clin Vaccine Immunol 14:1425-1432

Piedra PA, Gaglani MJ, Kozinetz CA, Herschler GB, Fewlass C, Harvey D, Zimmerman N, Glezen WP (2007) Trivalent live attenuated intranasal influenza vaccine administered during the 2003-2004 influenza type A (H3N2) outbreak provided immediate, direct, and indirect protection in children. Pediatrics 120:e553-e564

Pirhonen J, Sareneva T, Kurimoto M, Julkunen I, Matikainen S (1999) Virus infection activates IL-1 beta and IL-18 production in human macrophages by a caspase-1-dependent pathway. $\mathrm{J}$ Immunol 162:7322-7329

Price GE, Gaszewska-Mastarlarz A, Moskophidis D (2000) The role of alpha/beta and gamma interferons in development of immunity to influenza A virus in mice. J Virol 74:3996-4003

Qiao C, Yu K, Jiang Y, Li C, Tian G, Wang X, Chen H (2006) Development of a recombinant fowlpox virus vector-based vaccine of H5N1 subtype avian influenza. Dev Biol 124:127-132

Renegar KB, Small PA Jr (1991) Passive transfer of local immunity to influenza virus infection by IgA antibody. J Immunol 146:1972-1978

Rivetti D, Jefferson T, Thomas R, Rudin M, Rivetti A, Di Pietrantonj C, Demicheli V (2006) Vaccines for preventing influenza in the elderly. Cochrane Database Syst Rev 3:CD004876

Rizzo C, Viboud C, Montomoli E, Simonsen L, Miller MA (2007) A case-control study of elderly patients with acute respiratory illness: effect of influenza vaccination on admission to hospital in winter 2003-2004. Vaccine 25:7909-7913

Roti M, Yang J, Berger D, Huston L, James EA, Kwok WW (2008) Healthy human subjects have CD4+ T cells directed against H5N1 influenza virus. J Immunol 180:1758-1768

Roy S, Kobinger GP, Lin J, Figueredo J, Calcedo R, Kobasa D, Wilson JM (2007) Partial protection against $\mathrm{H} 5 \mathrm{~N} 1$ influenza in mice with a single dose of a chimpanzee adenovirus vector expressing nucleoprotein. Vaccine 25:6845-6851

Russell CJ, Webster RG (2005) The genesis of a pandemic influenza virus. Cell 123:368-371 
Saha S, Yoshida S, Ohba K, Matsui K, Matsuda T, Takeshita F, Umeda K, Tamura Y, Okuda K, Klinman D, Xin KQ, Okuda K (2006) A fused gene of nucleoprotein (NP) and herpes simplex virus genes (VP22) induces highly protective immunity against different subtypes of influenza virus. Virology 354:48-57

Sambhara S, Woods S, Arpino R, Kurichh A, Tamane A, Underdown B, Klein M, Lövgren Bengtsson K, Morein B, Burt D (1998) Heterotypic protection against influenza by immunostimulating complexes is associated with the induction of cross-reactive cytotoxic T lymphocytes. J Infect Dis 177:1266-1274

Saravolac EG, Sabuda D, Crist C, Blasetti K, Schnell G, Yang H, Kende M, Levy HB, Wong JP (2001) Immunoprophylactic strategies against respiratory influenza virus infection. Vaccine 19:2227-2232

Saurwein-Teissl M, Lung TL, Marx F, Gschosser C, Asch E, Blasko I, Parson W, Bock G, Schonitzer D, Trannoy E, Grubeck-Loebenstein B (2002) Lack of antibody production following immunization in old age: association with CD8(+)CD28(-) T cell clonal expansions and an imbalance in the production of Th1 and Th2 cytokines. J Immunol 168:5893-5899

Schultz-Cherry S, Dybing JK, Davis NL, Williamson C, Suarez DL, Johnston R, Perdue ML (2000) Influenza virus (A/HK/156/97) hemagglutinin expressed by an alphavirus replicon system protects chickens against lethal infection with Hong Kong-origin H5N1 viruses. Virology 278:55-59

Sekellick MJ, Carra SA, Bowman A, Hopkins DA, Marcus PI (2000) Transient resistance of influenza virus to interferon action attributed to random multiple packaging and activity of NS genes. J Interferon Cytokine Res 20:963-970

Senne DA (2007) Avian influenza in North and South America, 2002-2005. Avian Dis 51:167-173

Senne DA, Suarez DL, Stallnecht DE, Pedersen JC, Panigrahy B (2006) Ecology and epidemiology of avian influenza in North and South America. Dev Biol 124:37-44

Seo SH, Hoffmann E, Webster RG (2002) Lethal H5N1 influenza viruses escape host anti-viral cytokine responses. Nat Med 8:950-954

Seo SH, Hoffmann E, Webster RG (2004) The NS1 gene of H5N1 influenza viruses circumvents the host anti-viral cytokine responses. Virus Res 103:107-113

Shi H, Liu XF, Zhang X, Chen S, Sun L, Lu J (2007) Generation of an attenuated H5N1 avian influenza virus vaccine with all eight genes from avian viruses. Vaccine 25:7379-7384

Slepushkin VA, Katz JM, Black RA, Gamble WC, Rota PA, Cox NJ (1995) Protection of mice against influenza A virus challenge by vaccination with baculovirus-expressed M2 protein. Vaccine 13:1399-1402

Smith W, Andrewes CH, Laidlaw PP (1933) A virus obtained from influenza patients. Lancet 2:66-68

Smith S, Demicheli V, Di Pietrantonj C, Harnden A, Jefferson T, Matheson N, Rivetti A (2006) Vaccines for preventing influenza in healthy children. Cochrane Database Syst Rev CD004879

Solana R, Mariani E (2000) NK and NK/T cells in human senescence. Vaccine 18:1613-1620

Steel J, Burmakina SV, Thomas C, Spackman E, García-Sastre A, Swayne DE, Palese P (2008) A combination in-ovo vaccine for avian influenza virus and Newcastle disease virus. Vaccine 26:522-531

Steinhauer DA (1999) Role of hemagglutinin cleavage for the pathogenicity of influenza virus. Virology 258:1-20

Stephenson I, Bugarini R, Nicholson KG, Podda A, Wood JM, Zambon MC, Katz JM (2005) Crossreactivity to highly pathogenic avian influenza H5N1 viruses after vaccination with nonadjuvanted and MF59-adjuvanted influenza A/Duck/Singapore/97 (H5N3) vaccine: a potential priming strategy. J Infect Dis 191:1210-1215

Stott DJ, Carman WF, Elder AG (2001) Influenza in old age. Age Ageing 30:361-363

Subbarao K, Chen H, Swayne D, Mingay L, Fodor E, Brownlee G, Xu X, Lu X, Katz J, Cox N, Matsuoka Y (2003) Evaluation of a genetically modified reassortant H5N1 influenza A virus vaccine candidate generated by plasmid-based reverse genetics. Virology 305:192-200

Suguitan AL Jr, McAuliffe J, Mills KL, Jin H, Duke G, Lu B, Luke CJ, Murphy B, Swayne DE, Kemble G, Subbarao K (2006) Live, attenuated influenza A H5N1 candidate vaccines provide broad cross-protection in mice and ferrets. PLoS Med 3:e360 
Swain SL, Dutton RW, Woodland DL (2004) T cell responses to influenza virus infection: effector and memory cells. Viral Immunol 17:197-209

Szretter KJ, Gangappa S, Lu X, Smith C, Shieh WJ, Zaki SR, Sambhara S, Tumpey TM, Katz JM (2007) Role of host cytokine responses in the pathogenesis of avian H5N1 influenza viruses in mice. J Virol 81:2736-2744

Tamura S, Kurata T (2004) Defense mechanisms against influenza virus infection in the respiratory tract mucosa. Jpn J Infect Dis 57:236-247

Tamura S, Miyata K, Matsuo K, Asanuma H, Takahashi H, Nakajima K, Suzuki Y, Aizawa C, Kurata T (1996) Acceleration of influenza virus clearance by Th1 cells in the nasal site of mice immunized intranasally with adjuvant-combined recombinant nucleoprotein. J Immunol 156:3892-3900

Topham DJ, Tripp RA, Doherty PC (1997) CD8+ T cells clear influenza virus by perforin or Fasdependent processes. J Immunol 159:5197-5200

Tran TH, Nguyen TL, Nguyen TD, Luong TS, Pham PM, Nguyen VC, Pham TS, Vo CD, Le TQ, Ngo TT, Dao BK, Le PP, Nguyen TT, Hoang TL, Cao VT, Le TG, Nguyen DT, Le HN, Nguyen KT, Le HS, Le VT, Christiane D, Tran TT, Menno de J, Schultsz C, Cheng P, Lim W, Horby P, Farrar J; World Health Organization International Avian Influenza Investigative Team (2004) Avian influenza A (H5N1) in 10 patients in Vietnam. N Engl J Med 350:1179-1188

Treanor J, Kotloff K, Betts R, Belshe R, Newman F, Iacuzio D, Wittes J, Bryant M (1999) Evaluation of trivalent, live, cold-adapted (CAIV-T) and inactivated (TIV) influenza vaccines in prevention of virus infection and illness following challenge of adults with wild-type influenza A (H1N1), A (H3N2), and B viruses. Vaccine 18:899-906

Treanor JJ, Campbell JD, Zangwill KM, Rowe T, Wolff M (2006) Safety and immunogenicity of a recombinant of an inactivated subvirion influenza A (H5N1) vaccine. N Engl J Med 354:1343-1351

Tsuru S, Fujisawa H, Taniguchi M, Zinnaka Y, Nomoto K (1987) Mechanism of protection during the early phase of a generalized viral infection. II. Contribution of polymorphonuclear leukocytes to protection against intravenous infection with influenza virus. J Gen Virol 68:419-424

Tumpey TM, Basler CF, Aguilar PV, Zeng H, Solórzano A, Swayne DE, Cox NJ, Katz JM, Taubenberger JK, Palese P, García-Sastre A (2005) Characterization of the reconstructed 1918 Spanish influenza pandemic virus. Science 310:77-80

Tumpey TM, Maines TR, Van Hoeven N, Glaser L, Solórzano A, Pappas C, Cox NJ, Swayne DE, Palese P, Katz JM, García-Sastre A (2007) A two-amino acid change in the hemagglutinin of the 1918 influenza virus abolishes transmission. Science 315:655-659

Tweed SA, Skowronski DM, David ST, Larder A, Petric M, Lees W, Li Y, Katz J, Krajden M, Tellier R, Halpert C, Hirst M, Astell C, Lawrence D, Mak A (2004) Human illness from avian influenza H7N3, British Columbia. Emerg Infect Dis 10:2196-2199

Van Reeth K, Van Gucht S, Pensaert M (2002) In vivo studies on cytokine involvement during acute viral respiratory disease of swine: troublesome but rewarding. Vet Immunol Immunopathol 87:161-168

Williams AE, Edwards L, Humphreys IR, Snelgrove R, Rae A, Rappuoli R, Hussell T (2004) Innate imprinting by the modified heat-labile toxin of Escherichia coli (LTK63) provides generic protection against lung infectious disease. J Immunol 173:7435-7443

Yap KL, Ada GL (1978) The recovery of mice from influenza virus infection: adoptive transfer of immunity with immune T lymphocytes. Scand J Immunol 7:389-397

Zhang M, Zharikova D, Mozdzanowska K, Otvos L, Gerhard W (2006) Fine specificity and sequence of antibodies directed against the ectodomain of matrix protein 2 of influenza $A$ virus. Mol Immunol 43:2195-2206

Zheng B, Han S, Takahashi Y, Kelsoe G (1997) Immunosenescence and germinal center reaction. Immunol Rev 160:63-77

Zychlinsky A, Karim M, Nonacs R, Young JD (1990) A homogeneous population of lymphokineactivated killer (LAK) cells is incapable of killing virus-, bacteria-, or parasite-infected macrophages. Cell Immunol 125:261-267 